\title{
Prevalence of visible injuries to leatherback sea turtles Dermochelys coriacea in the Northwest Atlantic
}

\author{
Devan W. Archibald ${ }^{1}$, Michael C. James ${ }^{2, *}$ \\ ${ }^{1}$ Canadian Sea Turtle Network, Halifax, NS B3L 2T2, Canada \\ ${ }^{2}$ Population Ecology Division, Fisheries and Oceans Canada, Bedford Institute of Oceanography, Dartmouth, NS B2Y 4A2, Canada
}

\begin{abstract}
Identification and understanding of various patterns of injury in marine species such as cetaceans and sea turtles can elucidate corresponding threats and inform conservation efforts. Here we used standardized external injury assessments to investigate the relative importance of direct anthropogenic and natural threats to the Northwest Atlantic population of leatherback turtles Dermochelys coriacea, and to evaluate whether susceptibility to these threats varies between low-latitude nesting and high-latitude foraging regions, and by sex and size (i.e. age). We sampled leatherbacks foraging in temperate waters off Nova Scotia, Canada $(n=92)$, and at a nesting beach in Trinidad, West Indies $(n=137)$, where, combined, $62 \%$ of turtles exhibited characteristic markings associated with at least 1 injury (i.e. entanglement scarring, amputations, bites, etc.). There were no significant differences in injury rate or type between regions or between sexes or size classes. The proportion of leatherbacks exhibiting injuries of suspected anthropogenic origin $(34 \%)$ was significantly higher $(\mathrm{p}<0.001)$ than the proportion with injuries of suspected predatory origin $(16 \%)$, but did not exceed the proportion with injuries of unknown origin $(34 \%)$. Nineteen percent exhibited injuries indicative of entanglement in rope, lines, or nets, and $17 \%$ showed evidence of potential interaction with hooks. These results suggest that the Northwest Atlantic leatherback population faces common and possibly widely distributed threats from both predators and fishing gear across its range and are consistent with growing evidence positing fisheries bycatch as one of the principal direct threats facing this species.
\end{abstract}

KEY WORDS: Injury · Threats · Bycatch · Dermochelys coriacea $\cdot$ Sea turtle Predation · Entanglement · Trauma

\section{INTRODUCTION}

Marine animals face numerous natural and anthropogenic hazards of varying incidence and severity throughout their lives (Kappel 2005). Threats from natural sources include predation, competition, and disease, while pollution (Perrault et al. 2013, Camedda et al. 2014, Schuyler et al. 2014), overexploitation (Mancini \& Koch 2009), boat traffic, acoustic disturbances, bycatch (Moore et al. 2010, Casale 2011), and entanglement in active and discarded fishing gear (Knowlton et al. 2012, Moore \& van der Hoop

${ }^{*}$ Corresponding author: mike.james@dfo-mpo.gc.ca
2012, Komoroske \& Lewison 2015, Duncan et al. 2017) factor among impacting human activities. Identification and understanding of these threats is critical to management and conservation of species at risk (Lawler et al. 2002). With highly migratory, longlived species such as cetaceans and sea turtles, quantifying the relative impact of threats can be especially challenging. This may explain why assessment of the relative importance of multiple threats using conventional approaches typically employs semi-quantitative ranking systems (e.g. Donlan et al. 2010, Wallace et al. 2011).

(C) D. W. Archibald and Fisheries and Oceans Canada 2018. Open Access under Creative Commons by Attribution Licence. Use, distribution and reproduction are unrestricted. Authors and original publication must be credited.

Publisher: Inter-Research · www.int-res.com 
Injury assessment of individuals presents an alternative method for investigating the relative importance of multiple types of direct threats to a species. Distinctive markings associated with fresh or healed tissue damage can be diagnostic of interaction with anthropogenic hazards (e.g. impact from vessel propellers, entanglement in fishing rope) or natural encounters (e.g. shark bites, whale or shark rake marks). Therefore, classification of the suspected cause of injuries allows for evaluation of threat prevalence and investigation of potential variables that may affect individual vulnerability to threats. This approach is routinely used to assess the prevalence of anthropogenic threats affecting cetaceans (e.g. Knowlton \& Kraus 2001, Robbins \& Mattila 2004) and semi-aquatic turtles (Saumure et al. 2007). Similar methods have facilitated estimation of predation rates in a variety of taxa, including cetaceans (Heithaus 2001), fish (Reimchen 1988), invertebrates (Murtaugh 1981, McCallum et al. 1989), rays (Marshall \& Bennett 2010), and sea turtles (Heithaus et al. 2002), and have also been used to investigate the relative impact of both natural and anthropogenic threats to cetaceans (Kiszka et al. 2008, Luksenburg 2014), aquatic turtles (Cecala et al. 2009, Bennett \& Litzgus 2014), and whale sharks (Speed et al. 2008). It is important to recognize that a key bias inherent in these types of studies is that only individuals surviving injury are sampled. Sampling restricted to dead or compromised individuals that wash ashore (i.e. stranded) offers an alternative approach for investigating incidence of injury that has often been used with sea turtles (e.g. Chaloupka et al. 2008, Tomás et al. 2008) and cetaceans (e.g. Leeney et al. 2008, Nemiroff et al. 2010); however, it is clearly biased towards underestimating both incidence of injury and survival rates. While of limited value for estimating injury survival rates, injury assessments of live animals are advantageous in that they do not rely on drifting/ocean circulation patterns for sampling (as by default in stranding studies), thereby contributing to a potentially more robust indication of the relative magnitude of threats to the broader population. When combined with information gained from stranding studies, this approach can yield important insights into the nature, severity, and prevalence of threats facing marine animals.

Globally, 6 of the 7 species of sea turtle are categorized as at risk by the International Union for the Conservation of Nature (IUCN) (IUCN Red List version 2017, www.iucnredlist.org). Fisheries bycatch is now considered one of the largest direct threats fac- ing sea turtles globally (Donlan et al. 2010, Wallace et al. 2011). Both Donlan et al. (2010) and Wallace et al. (2011) concluded that sea turtles are impacted by multiple threats simultaneously, with relative vulnerability within species varying by geographic region (Donlan et al. 2010) or regional management unit (RMU) (Wallace et al. 2011). Due to the large distances (routinely thousands of kilometres) separating some sea turtle foraging and breeding areas, threats may also vary within a RMU. In addition, within a given geographic area, sea turtle life history stage or sex may cause variation in susceptibility to threats (Bolten et al. 2011). However, studies investigating the relative importance of multiple threats to specific populations of sea turtles, and how these threats vary across geographic ranges, life stages, or sexes are rare.

The leatherback sea turtle Dermochelys coriacea has the most extensive geographic range of any reptile (Eckert et al. 2012), and faces numerous anthropogenic threats in its marine and terrestrial habitat. Threats include pollution (e.g. Guirlet et al. 2010, Stewart et al. 2011, Perrault et al. 2013), plastic ingestion (e.g. Mrosovsky et al. 2009), coastal development (e.g. Bourgeois et al. 2009, Roe et al. 2013), climate change (e.g. Fish et al. 2005), and direct take of eggs and adults (e.g. Fossette et al. 2008, Tomillo et al. 2008, Revuelta et al. 2015). Leatherbacks are also susceptible to bycatch and entanglement in active and discarded fishing gear (Lewison et al. 2004, 2014, James et al. 2005b, Fiedler et al. 2012), which can leave distinctive external injuries on the shoulders, neck, head, and carapace caused by rope, netting, and hooks (Innis et al. 2010, Eckert et al. 2012). Leatherbacks are predated by large sharks - including white sharks Carcharodon carcharias and tiger sharks Galeocerdo cuvier - and also killer whales Orcinus orca (Heithaus et al. 2008), all of which can leave distinctive wounds. Natural predation has been shown to shape the behaviour and habitat use of cheloniid turtle species (Heithaus et al. 2002, 2008), but little is known about the prevalence of leatherback sea turtle interactions with predators. Here we summarize the results of external injury assessments of North Atlantic leatherback sea turtles to (1) clarify the relative importance of direct anthropogenic versus natural threats, (2) explore potential size- or sexrelated variation in injury rates and types, and (3) compare incidence of threats between an important temperate foraging area (Atlantic Canadian waters) and associated nesting beach (Trinidad, West Indies). 


\section{MATERIALS AND METHODS}

External injury assessments were conducted on foraging leatherbacks Dermochelys coriacea directcaptured in the summers of 2012 through 2015 (2012: 22 June to 3 September; 2013: 12 July to 31 August; 2014: 20 July to 26 August; 2015: 11 July 11 to 23 August) at 2 field sites in temperate waters off Nova Scotia, Canada, in support of a long-term research and monitoring programme that includes collection of biotelemetric, physiological, and morphological data (see James et al. 2005a,b, 2006, 2007, Stewart et al. 2013, Wallace et al. 2014, 2015). The nesting origins of leatherbacks that forage in Canadian Atlantic waters include beaches throughout the western Atlantic, with the majority ( $57 \%)$ representing a stock that includes Trinidad, West Indies (Stewart et al. 2013). Therefore, to collect comparative data from nesting animals, external injury assessments were also conducted between 30 May and 2 June 2014 and 14 and 19 April 2015 on female leatherbacks encountered on sections of Matura beach, Trinidad (approximately $10^{\circ} \mathrm{N}, 61^{\circ} \mathrm{W}$ ), an $\sim 8 \mathrm{~km}$ stretch of coastline that supports nesting by $\sim 1000$ to 2500 leatherbacks each year (Turtle Expert Working Group 2007). Flipper tag recoveries and post-nesting satellite tracks have revealed that leatherbacks nesting in Trinidad and other areas of the Wider Caribbean forage not only in Atlantic Canadian waters, but also in oceanic and coastal waters throughout the temperate North Atlantic, (e.g. Eckert 2006, Richardson et al. 2013).

In the present study, leatherbacks sampled in Canada and Trinidad were visually examined for the presence of external injuries or abnormalities. The flippers, tail, carapace, head, jaw, neck, and shoulder regions were consistently examined. Visibility was reduced during examinations of turtles on the nesting beach because they were conducted at night and turtles were normally partially buried in sand (the plastron was not visible and the bridge between plastron and carapace was not consistently visible, so injuries to these regions were underrepresented). Moreover, sand scattered on nesting turtles could obscure potentially relevant markings. To help address these challenges, once egg laying had commenced, turtles were briefly illuminated and sand was removed with a hand-held whisk. Injuries were categorized by condition: fresh (acute, without scabbing present), partially healed (scabbing present), or healed (scar, with no scabbing remaining); and they were also classified as indicative of suspected anthropogenic, predatory, or unknown origin.
We classified injuries of suspected anthropogenic origin into 3 principal categories: (1) entanglement in line, rope, or nets, (2) hooks, and (3) vessel strikes. Wounds, markings, and/or scarring indicative of line entanglement normally included characteristic abrasions or lacerations encircling or partially encircling the humerus and often also the neck, consistent with those directly observed on turtles released from entangling lines and/or found stranded with lines still attached (see Figs. 1A,B \& 2A, $B_{i}$ Innis et al. 2010, Eckert et al. 2012). Injuries attributed to interactions with hooks were exemplified by puncture wounds on the shoulder and/or neck regions, typically with raised scar tissue present, indicating tissue rejection of the hook, or tear-out (see Figs. 1C,D \& 2C,D; Watson et al. 2005). The mouth and cloaca were also inspected for protruding fishing line (possibly indicative of hook ingestion). Injuries characteristic of vessel strikes were exemplified by parallel, evenly spaced lacerations on the carapace - which we attributed to propellers and sometimes the presence of anti-fouling paint, consistent with impact from a boat hull (see Fig. 1E,F; Work et al. 2010, Eckert et al. 2012).

Injuries of suspected predatory origin observed in this study included rake marks or other damage indicative of shark or killer whale interaction (see Fig. 3A $i$ Luksenburg 2014); partial or complete amputation of flippers with accompanying circular, shredded, or jagged edges (see Fig. 3B; Horrocks 1989, Heithaus et al. 2002, Marshall \& Bennett 2010); missing semi-circular sections (see Fig. $3 C_{i}$ Heithaus et al. 2002, Eckert et al. 2012); as well as lacerations in the head region in combination with any of the prior indicative injuries (see Fig. 3D). Note that in this study, only flippers with $>1 / 3$ surface area missing or impacted were included; minor tears and abnormalities often seen on flipper margins were excluded as too ambiguous to assign to suspected predator interaction.

In addition to injuries for which probable origins were most evident, we also noted any other external abnormalities of unknown origin $>5 \mathrm{~cm}$ in length or width. Superficial scrapes or very small wounds $(<5 \mathrm{~cm})$ not readily discernible as characteristic of anthropogenic interaction or predation as described above were not consistently noted and were excluded from the analysis (e.g. small pieces missing from flipper margins, wounds from detached barnacles, etc.). Multiple injuries of the same type impacting 1 region were counted as 1 injury (e.g. numerous rake marks on the carapace). If the injury spanned the boundary between any 2 generalized body 'regions' (e.g. carapace and neck), both 'regions' were recorded as impacted but the injury was counted as 1 injury. Sep- 


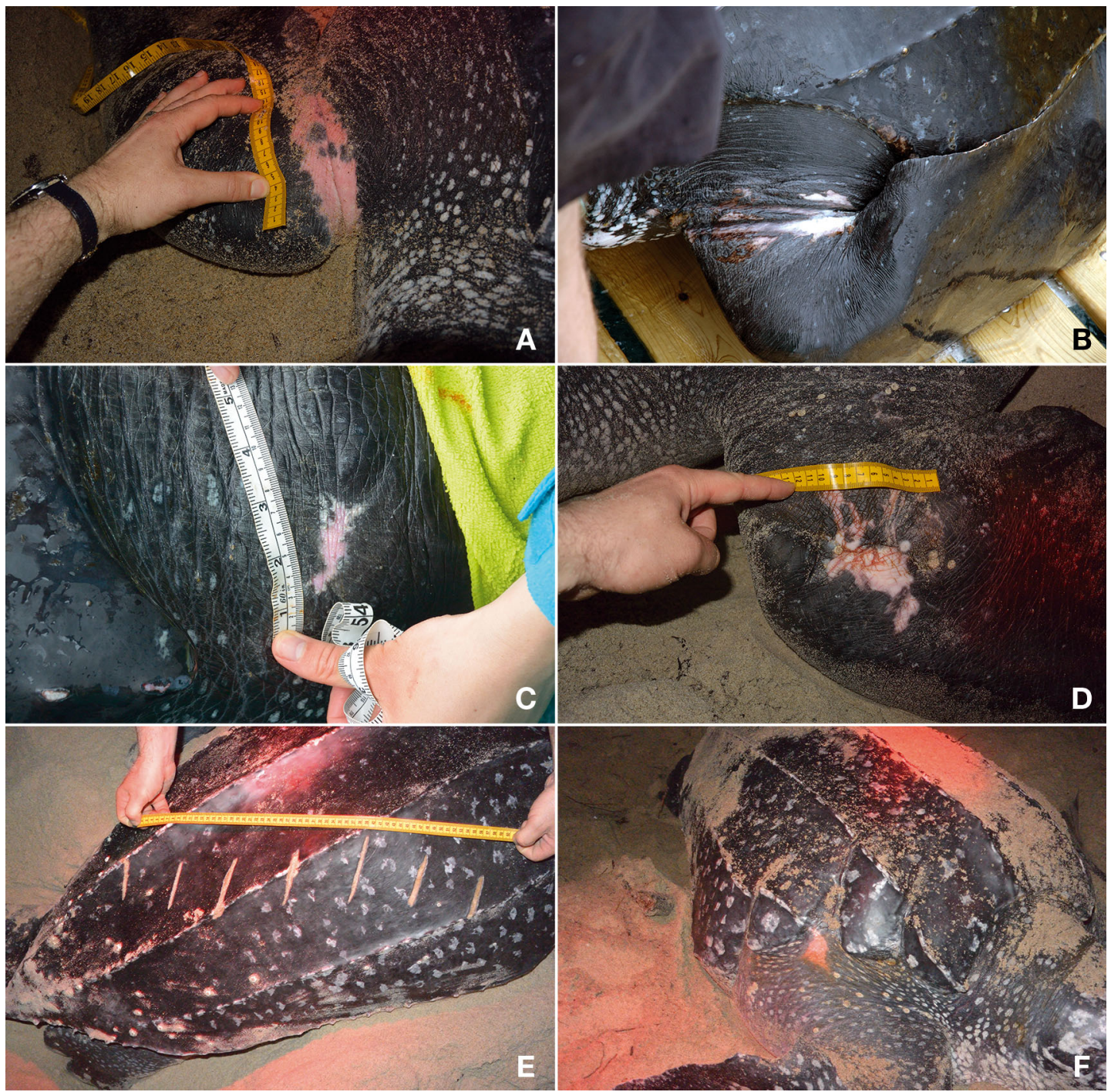

Fig. 1. Injuries of suspected anthropogenic origin among subadult and adult Northwest Atlantic leatherback turtles Dermochelys coriacea included abnormalities indicative of $(\mathrm{A}, \mathrm{B})$ rope, line, or net entanglement (abrasions or lacerations encircling or partially encircling the shoulder and/or neck regions); $(C, D)$ hooks (puncture wounds on the shoulder and/or neck regions,

typically with raised scar tissue); and (E,F) boat strikes (parallel lacerations on carapace likely caused by propellers)

arate body regions affected by similar injuries were counted as distinct injuries if they were not joined. If injuries clearly seemed to have occurred at different times (i.e. scar with an acute wound overtop), they were counted as distinct injuries.

We photographed nearly all injuries. These images were later referenced to reassess and confirm injury classifications made in the field. In addition, during handling, curved carapace length (CCL) and sex was recorded. In Canadian waters, leatherbacks with existing flipper or passive integrated transponder (PIT) tags (previously applied on a nesting beach) were recorded as female and those displaying a phallus were recorded as male. If neither of these criteria were met, for individuals with a CCL $>145 \mathrm{~cm}$, sex was assessed based on tail length. In the absence of phallus display, sex of individuals smaller than this size was categorized as undetermined.

Chi-square tests were used to determine whether there were differences in either the proportions of injuries, or the proportions of turtles with at least 1 injury of a given type among categories or groups. For those cells in contingency tables containing a value of 5 or fewer, Fishers exact tests were used instead. When comparisons of more than 2 groups or categories revealed significant differences, pairwise tests with Bonferroni corrected p-values were used to investigate for significant differences. Multiple sepa- 

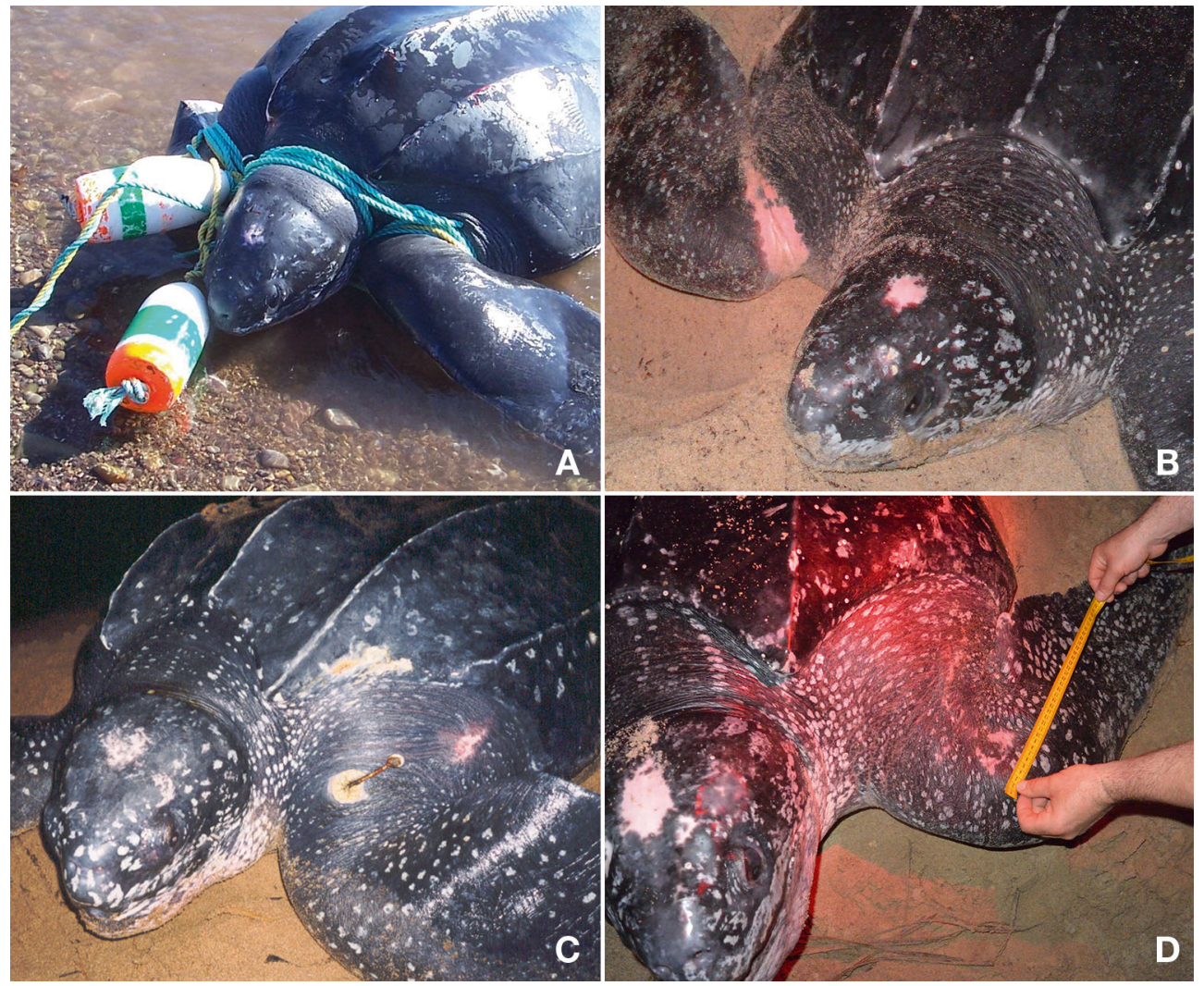

Fig. 2. Leatherback turtles Dermochelys coriacea exhibiting $(A, C)$ confirmed fishery-related injuries (turtles not included in this study) and $(\mathrm{B}, \mathrm{D})$ characteristic congruent scarring patterns indicative of fishery interactions (turtles included in this study). (A,B) Rope entanglement: (A) turtle entangled in polypropylene rope and (B) a nesting turtle with scarring encircling the humerus. $(\mathrm{C}, \mathrm{D})$ Embedded hook: $(\mathrm{C})$ hook lodged in the shoulder region and (D) shoulder scarring consistent with hook puncture wound

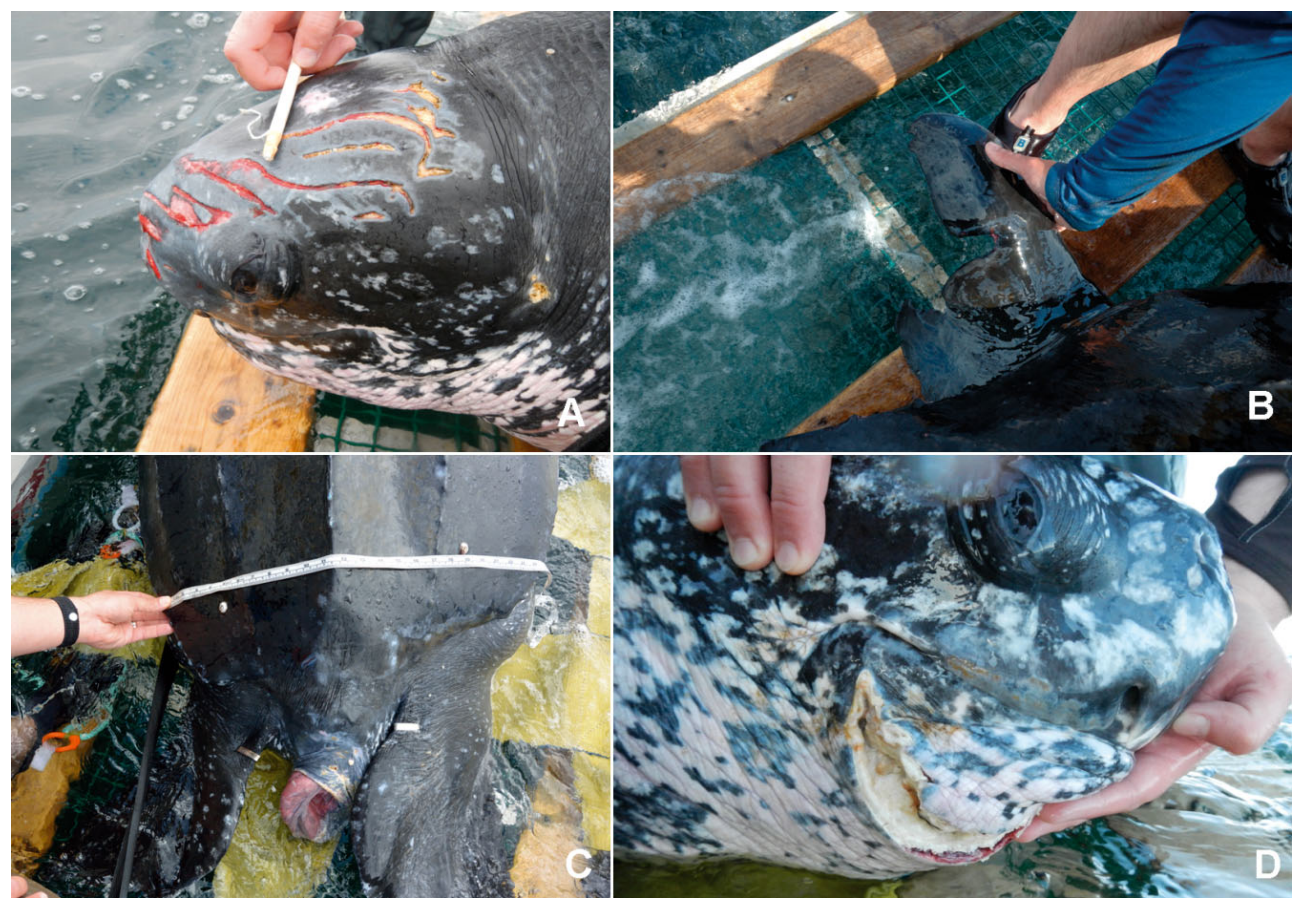

Fig. 3. Injuries indicative of predatory origin from shark or killer whale interaction among leatherback turtles Dermochelys coriacea live-captured in Atlantic Canada included (A) rake marks, (B) partial or complete amputation of flippers with a circular, shredded or jagged appearance, (C) semi-circular sections of the carapace missing (and, in this case, also part of the tail), and (D) lacerations in the head region in combination with any of the prior indicative injuries 
rate generalized linear models (GLMs) with binomial distributions and logit links (Venables \& Ripley 2002) were used to test for a size (CCL) effect on the proportions of turtles with at least 1 injury of various types. All statistical analyses were conducted using the statistical software R (R Core Team 2016) with an alpha level of 0.05 .

\section{RESULTS}

A total of 228 individual leatherback turtles were examined, with a mean CCL of $154.1 \pm 0.55 \mathrm{~cm}$ (range $122.3-174.2 \mathrm{~cm}$; median CCL $=154.7 \mathrm{~cm}$ ). A total of 281 injuries were observed during 229 injury assessments (Atlantic Canada in-water sampling, $\mathrm{n}=92$; Trinidad nesting beach, $\mathrm{n}=137$ ). One turtle was livecaptured and examined on 2 occasions off Atlantic Canada, $795 \mathrm{~d}$ apart. Given that over $2 \mathrm{yr}$ had passed between examinations, and that different injuries were noted each time, this turtle was treated as an independent sample and is included twice in the summary data.

At least 1 injury was detected in $62.0 \%$ of injury assessments ( $\mathrm{n}=142$ turtles). For those turtles which exhibited evidence of injury, multiple injuries were the norm $($ mean $=1.98 \pm 0.11$, median $=1.0$, range $=$ 1.0-9.0). The proportion of injuries was significantly different between each condition category $(p<0.001$, $\left.\chi^{2}=228.1\right)$, with the majority of injuries $(\mathrm{n}=281$ injuries) classified as healed $(61.6 \%)$ or partially healed $(36.7 \%)$, and very few classified as fresh $(1.8 \%)$. The proportion of injuries was significantly different between various body regions $(\mathrm{p}<0.001$, $\chi^{2}=346.7$ ), with the majority located on and around the shoulder/humerus region $(39.1 \%)$, carapace $(27.4 \%)$, and flippers $(16.7 \%)$. To a lesser extent, injuries were found on the head $(8.2 \%)$, neck $(6.0 \%)$, and bridge joining the plastron and carapace $(3.2 \%)$. Very few injuries were found on the jaw $(0.007 \%)$ and tail $(0.007 \%)$. For those injuries (any type) found on the shoulder region, a significantly higher proportion were found on the left rather than the right side $\left(57.3 \%\right.$ versus $\left.42.7 \% ; p<0.043, \chi^{2}=4.09\right)$. Within injuries found on flippers, there were no significant differences $\left(p=0.32, \chi^{2}=3.49\right)$ between the proportion found on the front left $(19.1 \%)$, front right $(29.8 \%)$, rear left $(31.9 \%)$, and rear right $(19.1 \%)$ flippers.

Overall, there was no significant difference $(p=$ $0.92, \chi^{2}=0.17$ ) in the proportion of leatherbacks with injuries among males $(60.9 \%, \mathrm{n}=23)$, females $(62.5 \%$, $\mathrm{n}=192)$, and those of unknown sex $(57.1 \%, \mathrm{n}=14)$; nor was there a significant difference $\left(p=0.48, \chi^{2}=\right.$
0.50) between sampling areas (Canada: $58.7 \%$; Trinidad: $64.2 \%$ ). There was also no significant effect of CCL on the proportion of leatherbacks exhibiting injuries $\left(\mathrm{GLM}_{i} \mathrm{p}=0.79, \chi^{2}=0.07_{1,222}\right)$. Therefore, turtles examined at both sampling sites were combined for further analyses.

The proportion of leatherbacks with injuries corresponding to each of the suspected origin categories varied significantly (Fig. 4 ; $\mathrm{p}<0.001, \chi^{2}=25.5$ ). The highest proportion of turtles exhibited injuries of suspected anthropogenic origin (34.1\%) and unknown origin $(34.1 \%)$, while the lowest proportion exhibited injuries of suspected predatory origin (15.7\%). Only $14.8 \%$ of turtles exhibited injuries consistent with 2 suspected origin categories and $3.5 \%$ exhibited injuries from all 3 categories (anthropogenic, predation, unknown).

There was a significant difference in the proportion of sampled leatherbacks presenting each of the 3 subcategories of injuries of suspected anthropogenic origin, $\left(p<0.001, \chi^{2}=39.1\right.$; Fig. 5). The proportion of leatherbacks with injuries $(\mathrm{p}<0.001$, $\chi^{2}=39.1$, Fig. 5). The lowest proportion of turtles exhibited injuries indicative of boat strikes $(1.3 \%)$, while the highest proportion of turtles exhibited injuries indicative of entanglement in rope, lines, or nets $(18.8 \%)$, or interaction with hooks $(17.0 \%)$. The latter injuries, which regularly present as puncture wounds with associated raised scarring, are often located in the pectoral region, where hooks are frequently observed following leatherback-pelagic

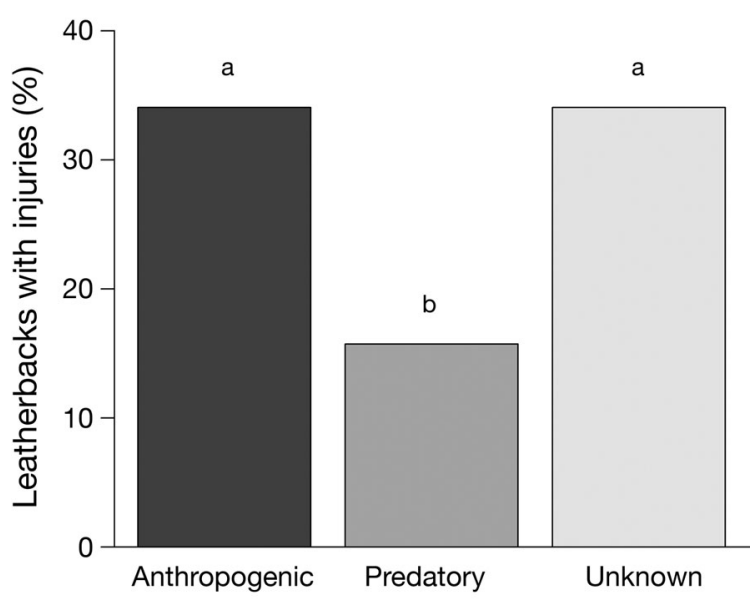

Fig. 4. For leatherback turtles Dermochelys coriacea sampled in Atlantic Canada and Trinidad combined ( $\mathrm{n}=229)$, there was a significant difference $\left(p<0.001, \chi^{2}=25.7\right)$ in the proportion of turtles with injuries among each of the suspected injury origin categories. Different letters above bar plots indicate significant differences $(\alpha=0.05)$ found using post hoc testing with Bonferroni corrected $\mathrm{p}$-values 


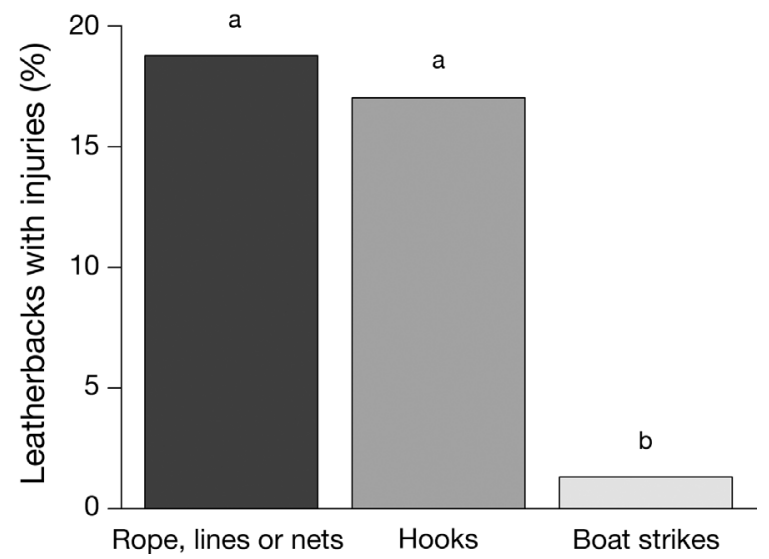

Fig. 5. For leatherback turtles Dermochelys coriacea sampled in Atlantic Canada and Trinidad combined $(\mathrm{n}=229)$, there was a significant difference $\left(p<0.001, \chi^{2}=25.5\right)$ in the proportion of turtles presenting each of the 3 subcategories of injuries of suspected anthropogenic origin. Different letters above bar plots indicate significant differences $(\alpha=0.05)$ found using post hoc testing with Bonferroni corrected $\mathrm{p}$-values

longline interactions (Watson et al. 2005). Only 1 turtle presented with a portion of the hook still clearly anchored in tissue, suggesting this species may have a strong capacity for tissue rejection of embedded foreign bodies, although many factors likely influence hook retention (e.g. time since hooking event, depth of hook, type of hook). Three leatherbacks included in this study were found entangled in fishing gear-all gear was removed immediately prior to their examination-however, none showed fresh injuries attributable to rope, lines, or nets (presumably they had not been entangled for long). Two of these turtles exhibited healed injuries attributable to rope, lines, or nets, indicating previous interaction with fishing gear.

Of the proportion of turtles that exhibited injuries of unknown origin $(34.1 \%, \mathrm{n}=78$ turtles), assorted anthropogenic and natural causes were likely implicated, but, in each case, we were unable to assign a suspected origin with certainty. For example, 14 turtles ( $\mathrm{n}=2$ turtles examined in Atlantic Canada $\mathrm{n}=12$ turtles examined in Trinidad) had injuries consisting of long, smooth, and straight slices, sometimes with resultant chunks missing from the carapace or flipper (Fig. 6A,B), which may have been caused by machete cuts associated with release from artisanal gill-nets, as documented by others (Livingstone 2006, Hilterman \& Goverse, 2007, Turtle Expert Working Group 2007). Four females examined in Trinidad had injuries on the top of their heads, potentially inflicted by mating attempts (Reina et al. 2005), and characterized by irregular scrapes near their pink spots (Fig. 6C,D). Similar injuries were not seen on turtles examined in Atlantic Canada.

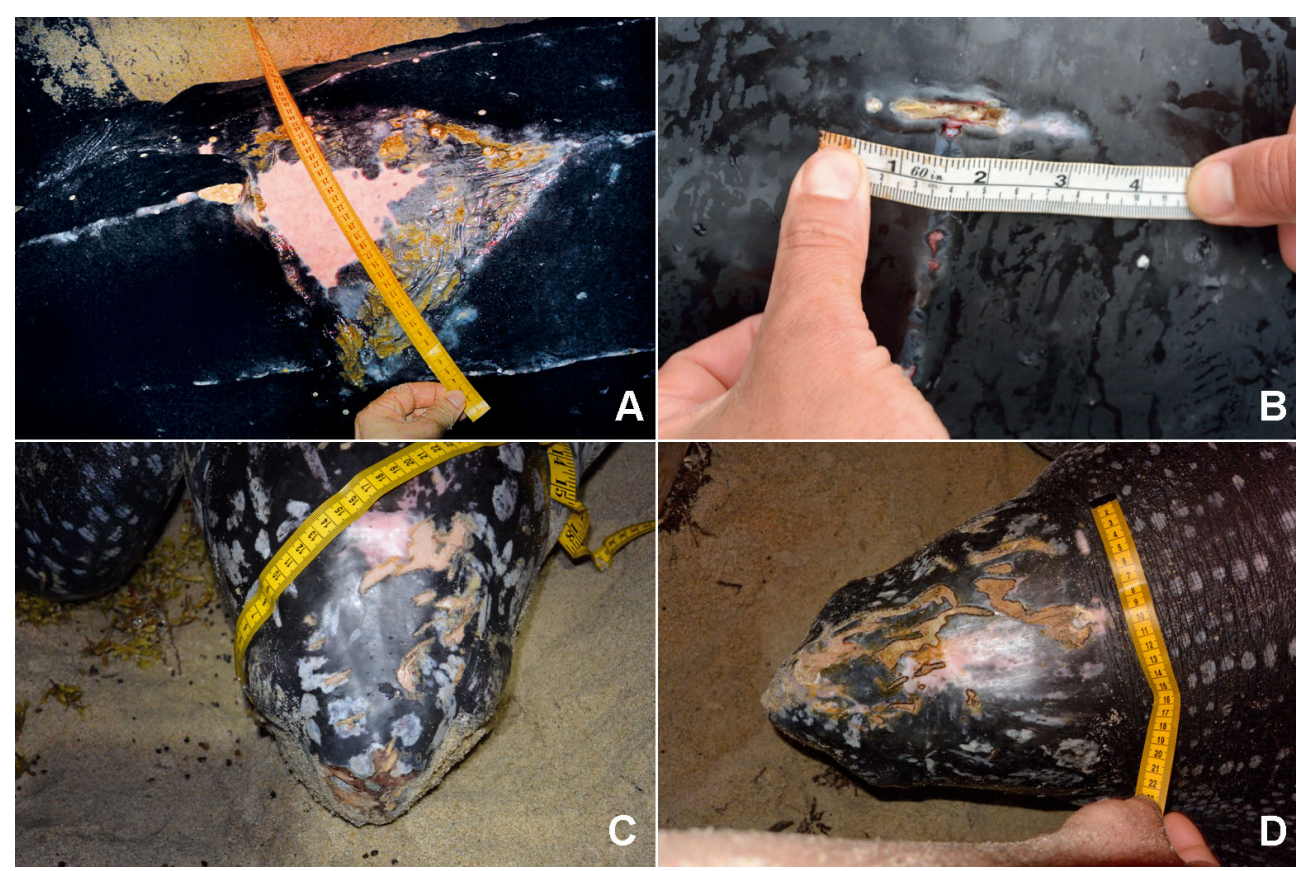

Fig. 6. Injuries of unknown origins were observed in $34.1 \%$ of all leatherback turtles Dermochelys coriacea. (A,B) Possible machete cuts were characterized by long, smooth, and straight slices, sometimes with resultant chunks missing from the carapace or flipper. $(\mathrm{C}, \mathrm{D})$ Possible biting injuries inflicted by males during mating attempts were characterized by irregular scrapes on the dorsal surface of the head 
There was no significant difference in the proportion of leatherbacks with injuries of suspected predatory origin among the sexes $(p=0.52$, Fisher's exact test) or between geographic sampling regions $(\mathrm{p}=1$, $\chi^{2}=0$ ), nor was there a significant effect of CCL $\left(G L M ; p=0.30, \chi^{2}=1.09_{1,222}\right)$. There was also no significant difference in the proportion of leatherbacks with injuries of suspected anthropogenic origin among the sexes $\left(p=0.44, \chi^{2}=1.66\right)$ or between sampling regions $\left(\mathrm{p}=0.54, \chi^{2}=0.38\right)$, and again, there was no significant effect of CCL $\left(G L M ; p=0.99, \chi^{2}=\right.$ $0.0001_{1,222}$ ). Similarly, there was no significant difference in the proportion of leatherbacks with injuries indicative of entanglement in ropes, lines, or nets among sexes ( $p=0.22$, Fisher's exact test), or between regions $\left(\mathrm{p}=0.14, \chi^{2}=2.13\right)$; nor was there a significant effect of CCL (GLM; $p=0.10, \chi^{2}=2.64_{1,222}$ ). There was a non-significant trend for a difference in the proportion of leatherbacks with injuries indicative of hooks among the sexes $(p=0.08)$, likely driven by the lower proportion observed in females (15.1\%), compared with the higher proportion among those of unknown sex $(35.7 \%)$, while males exhibited a proportion $(21.7 \%)$ comparable to both of these groups.
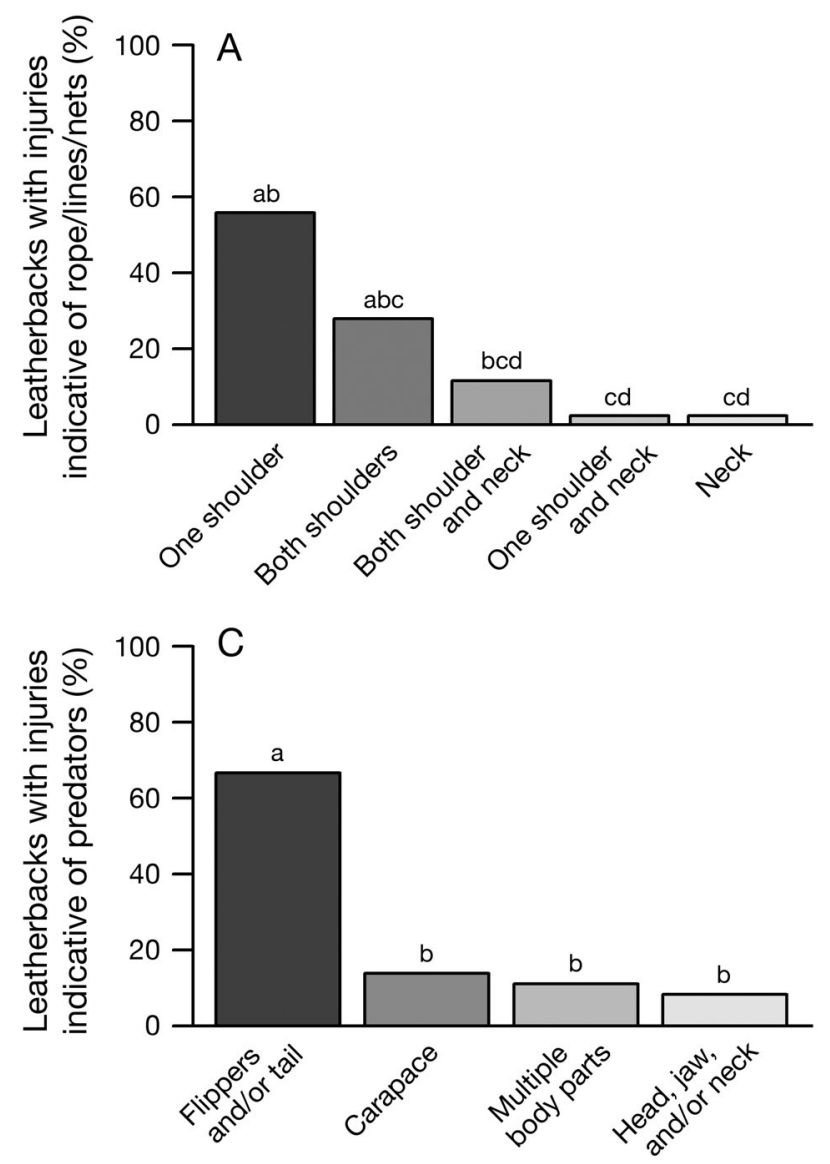

There was no significant difference in the proportion of leatherbacks with injuries indicative of hooks between the sampling regions $\left(p=0.68, \chi^{2}=0.18\right)$, nor was there a significant effect of CCL (GLM; $\mathrm{p}=0.24$, $\left.\chi^{2}=1.38_{1,222}\right)$. Although only females had injuries indicative of boat strikes, so few $(n=3)$ were noted that there was no significant difference in the proportion among the sexes ( $p=1.0$, Fisher's exact test) or between regions ( $p=0.28$, Fisher's exact test), nor was there a significant effect of CCL (GLM; $p=0.37$, $\chi^{2}=0.80_{1,222}$ ).

For those leatherbacks with injuries suspected to originate from entanglement in rope, lines, or nets ( $\mathrm{n}=43$ turtles), there was a significant difference $(\mathrm{p}<$ 0.001, Fig. 7A) in the proportion of turtles falling into each category of impacted body region. The highest proportions of leatherbacks exhibited such injuries on only one shoulder (55.8\%) or both shoulders $(27.9 \%)$. When one shoulder was implicated $(n=25)$, there was no significant difference $\left(p=0.57, \chi^{2}=\right.$ 0.32 ) between the proportion exhibiting injuries on the left $(56.0 \%)$ or right $(44.0 \%)$ shoulder. For leatherbacks with injuries suspected to originate from hooks ( $\mathrm{n}=39$ turtles), there was a significant differ-

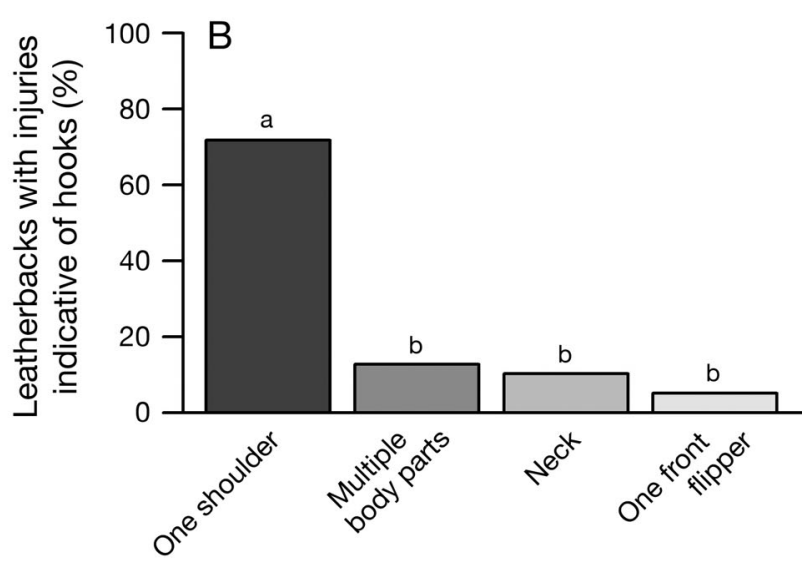

Fig. 7. Locations of external injuries among leatherback turtles Dermochelys coriacea sampled in Atlantic Canada and Trinidad combined that were indicative of entanglement in (A) rope, lines, or nets $(n=43)$; (B) hooks $(n=39)$; or $(C)$ predators $(n=36)$. Within each indicative category there was a significant difference (all with $p<0.001$ ) in the proportion of turtles with the indicative injury presenting on various body regions. Different letters above bar plots indicate significant differences $(\alpha=0.05)$ found using post hoc testing with Bonferroni corrected $\mathrm{p}$-values 
ence $(p<0.001$, Fig. $7 B$ ) in the proportion of turtles corresponding to the various categories of impacted body region. The most common site of suspected hook-related injury corresponded to one shoulder $(71.8 \%)$, and, for these turtles $(\mathrm{n}=28)$, there was a significant difference $\left(p<0.001, \chi^{2}=12.1\right)$ between the proportion exhibiting them on the left versus right shoulder ( $75 \%$ versus $25 \%$, respectively). Of the 3 turtles in the sample with injuries suspected to originate from boat strikes, 2 revealed carapacial scarring indicative of rotating propellers, and 1 individual exhibited a carapacial scrape with anti-fouling paint present.

Thirty-six leatherbacks exhibited injuries suspected to have originated from interactions with predators, and there was a significant difference $(p<0.001$, Fig. $7 \mathrm{C}$ ) in the proportions of turtles with injury to different body regions. The majority of predatorinduced injuries were apparent on the extremities only - namely the flippers and/or tail (66.7\%). For the 26 turtles bearing such injuries, there was a significant difference $(p=0.018)$ among the number presenting with damage to the various flippers (front and rear, right and left) or tail. The largest number of injuries were to the rear left flipper $(46.2 \%$ of individuals), which was significantly higher $(\mathrm{p}=0.039)$ than the number of injuries to the tail $(7.7 \%)$, but not significantly different (all pairwise $\mathrm{p}>0.34$ ) from the number of injuries on the front right flipper $(30.8 \%)$, rear right flipper $(26.9 \%)$, or front left flipper $(15.4 \%)$, respectively.

\section{DISCUSSION}

Over half $(62.0 \%)$ of the combined sample of leatherback turtles examined in foraging habitat off Atlantic Canada and at a major nesting site in Trinidad exhibited a minimum of 1 external injury, indicating that a large proportion of the subadult and adult turtles in the Northwest Atlantic leatherback population interact with (and survive) exposure to direct anthropogenic and/or natural threats. The prevalence of injuries reported here is markedly higher than that reported in an earlier study of overall injury rates among leatherbacks $(\mathrm{n}=6791)$ in French Guiana in the 1980 s ( $8 \%$; Fretey 1982), but similar to the $70.6 \%$ of nesting females $(n=34)$ recorded with 1 or more injuries at a nesting beach in Papua New Guinea about a decade later (Hirth et al. 1993). Consistent with the present study, recent health assessments of leatherbacks live-captured off the coast of New England and California found over half with previously healed injuries (New England: 52.6\%, n = 19, Innis et al. 2010; California: $89 \%, \mathrm{n}=19$, Harris et al. 2011). Collectively, the relatively high overall rate of injuries in more recent studies indicate that leatherbacks are widely susceptible to injury, and perhaps more so than they were in the past.

The proportion of leatherbacks with injuries of suspected anthropogenic origin reported here $(34.1 \%)$ was more than double the proportion with injuries of suspected predatory origin $(15.7 \%)$, implying that leatherbacks of the size class we studied may have a higher risk and incidence of injury due to anthropogenic versus natural causes (although many injuries were classified as unknown suspected origin). The suspected anthropogenic injury rate derived in the present study is higher than that reported in a sample of nesting leatherbacks in Suriname, where wounds and scars attributable to nets, hooks, propellers, or machetes were recorded $(2002: 9 \%$; 2003: $16.9 \%$; 2005: $18.3 \%$; Hilterman \& Goverse 2007). The higher rate reported here could reflect divergent examination protocols at different sites, a change in the level of threat over time, and/or regional effects. However, the latter possibility is unlikely given that a relatively large proportion of leatherbacks using Canadian foraging habitat originate from Suriname/ French Guiana nesting populations ( 25\%; Stewart et al. 2013). We suspect that the higher incidence of injury found in the present study at least partially reflects implementation of injury assessment field protocols specifically designed to detect and document the suite of potential injuries to leatherbacks (including near-complete removal of sand from nesting females and standardized photo-documentation), and enhanced visibility afforded by daytime examinations of turtles live-captured in Canadian waters. By contrast, recording of injuries by other nesting beach groups was often secondary to other research priorities, and, therefore, especially under consistently dark (night time) conditions, it is possible that mainly only the most conspicuous of injuries were seen and noted.

The majority of leatherback injuries suspected to originate from anthropogenic causes had characteristics consistent with turtle-fishery interactions: nearly 1 in 5 individuals (18.8\%) exhibited injuries indicative of entanglement in rope, lines, or nets and just over 1 in $6(17.0 \%)$ showed evidence of potential interaction with hooks. Remarkably, the incidence of each of these categories of anthropogenic interaction among our sample was higher than the proportion of leatherbacks showing evidence of natural predation $(15.7 \%)$, further highlighting a higher risk of injury due to 
human rather than natural causes, at least among turtles in the large size-class we sampled (subadult and adult animals). These results are consistent with growing evidence positing fisheries bycatch as one of the principal direct threats facing leatherbacks (Lewison et al. 2004, Donlan et al. 2010, Wallace et al. 2010). In addition, the large proportion of leatherbacks with injuries indicative of entanglement highlights the threat that fixed gear (James et al. 2005b, Hamelin et al. 2017) and gill nets (Lum 2006, Lewison \& Crowder 2007) pose to this species. Evidence of suspected hooking among our sample was also high, consistent with the regularity with which this species interacts with pelagic longline fisheries (Lewison et al. 2004).

Entanglement in fixed fishing gear has been posited as a principal anthropogenic threat to leatherbacks in waters off Atlantic Canada (Hamelin et al. 2017), while entanglement in gill nets is a leading cause of injury and mortality for the breeding population in Trinidad (Lum 2006). Turtle-fishery interactions in both regions from these sources result in similar injuries (e.g. tissue damage from vascular constriction or chafing on the shoulders and/or neck), making it difficult to attribute specific cases to even broad geographic areas, particularly when injuries are healed. What is clear, however, from visible injuries sustained through probable fishery interactions, is that lines, ropes, nets, and hooks present a regular hazard. This evidence for rope, line, and net interactions is consistent with patterns of leatherback-fishery interaction derived from reporting networks (rope, line; Hamelin et al. 2017) and fisher interviews (artisanal gill nets; Lum 2006), informing understanding of where research on fishing gear design and practices to mitigate leatherback bycatch might be effectively directed. Most turtles with observed line injuries appeared to exhibit normal movement and range of motion in affected body parts, although the extent of scaring in some cases suggests this may not have always been the case at the time of injury. Mortality rates estimated from interactions with fishing gear can be high (e.g. Àlvarez de Quevedo et al. 2013, Murray 2015, Alfaro-Shigueto et al. 2018). Our live sample does not account for the unknown, but likely significant, numbers of turtles that do not survive such interactions.

The present results likely also underestimate the number of leatherback-fishery interactions because not all interactions will result in scarring. Three leatherbacks included in this study were found entangled in fishing gear and all gear was removed immediately prior to their examination; however, none showed fresh injuries attributable to rope, lines, or nets (presumably they had not been entangled for long). Two of these turtles exhibited healed injuries attributable to rope, lines, or nets, indicating previous interaction with fishing gear; it is encouraging that these individuals survived at least 2 fishery interactions. Collectively, the present results might be interpreted as evidence for Northwest Atlantic leatherbacks regularly interacting with fishing gear, but also regularly surviving such interactions after they are carefully released. Thus, successful conservation efforts will require the continued engagement of commercial fishers (Martin \& James 2005a,b), armed with the knowledge of proper leatherback handling and release techniques.

While the large body size of adult leatherbacks is thought to reduce the threat of predation (Eckert et al. 2012), $15.7 \%$ of leatherbacks we examined had at least 1 injury of suspected predatory origin. Beyond rare reported observations of predatory interactions by sharks or killer whales (e.g. Caldwell \& Caldwell 1969, Long 1993, Oviedo et al. 2008), little is known about natural predation of post-hatchling leatherbacks, and subadult and adult turtles in particular. However, while previous accounts of predation and/ or attempted predation events in the Atlantic have been limited to lower-latitude habitat for leatherbacks (e.g. Caribbean: Caldwell \& Caldwell 1969, Bacon 1970, Horrocks 1989, Fretey 1993, Oviedo et al. 2009), documentation of relatively fresh (scabbed) partial flipper amputations and fresh rake marks and lacerations (e.g. Fig. 3) among a handful of turtles examined in waters off Canada (present study), attest to predator interactions occurring in high-latitude Northwest Atlantic foraging habitat, too.

Slightly over $1 / 3$ of the leatherbacks in our sample presented with injuries that we were unable to assign to suspected origin categories. These injuries of unknown origin likely reflect a mixture of anthropogenic and natural causes. We hypothesize that some of the unknown laceration injuries may have been caused by machetes, which may be used to release leatherbacks from artisanal gill nets (Livingstone 2006, Hilterman \& Goverse 2007, Turtle Expert Working Group 2007). These were more common in turtles sampled in Trinidad than Atlantic Canada, consistent with regular interaction of leatherbacks with artisanal gill nets in the region (Lum 2006). In addition, while previously documented evidence was insufficient to conclusively assign them to a separate injury category, we hypothesize that scrape injuries seen on the dorsal surface of the heads of 4 nesting females in Trinidad may reflect bites by male turtles during mat- 
ing attempts. This behaviour, and this type of probable associated injury, has been reported from other nesting areas (Reina et al. 2005, Perrault et al. 2012).

Here we present the first comparison of injury rates, using standardized recording methods, for a population of leatherbacks sampled at both high-latitude foraging and low-latitude breeding areas. There was no significant difference in the proportion of leatherbacks exhibiting injuries in waters off Atlantic Canada versus on the nesting beach in Trinidad, suggesting that leatherbacks in both areas are vulnerable to direct interaction with threats. There was no significant difference in the proportion of males, females, and subadult (unknown sex) leatherbacks exhibiting injuries, nor was there a significant effect of CCL, indicating similar risks of injury regardless of sex or size (i.e. age). Moreover, there were no significant effects of size or sex on the proportion of leatherbacks with injuries indicative of predatory origin or anthropogenic origin, nor within the 3 subcategories of anthropogenic origin we tested (interactions with lines, hooks, or vessels, respectively). This suggests that injury-linked interactions with both predators and anthropogenic sources constitute a generalized threat for this population, impacting subadult and mature leatherbacks of both sexes (our sample) somewhat uniformly. However, importantly, as examinations of turtles at both field sites (separated by $30+$ degrees of latitude) sampled animals from the same overall population (Northwest Atlantic), and the number of turtles presenting with fresh scarring at either field site was not high, the present results do not resolve when and where such injuries are most frequently sustained.

Sex differences have been found in shark-inflicted injury rates in a foraging population of loggerhead sea turtles Caretta caretta, suggesting males may exhibit riskier behaviour and face higher predation rates, possibly related to differential behaviour during reproduction or foraging-habitat use (Heithaus et al. 2002, 2005). Although the potential effect of sex was not explicitly tested for, fine-scale foraging ecology research on leatherbacks off the Atlantic coast of Canada suggests little difference in foraging behaviour among males, females, and subadults (Wallace et al. 2015). However, satellite tracking of males indicates that, compared with nesting females, at some rookeries, males spend equal or more time adjacent to beaches (James et al. 2005a), where fishing efforts may be concentrated (Lum 2006). In addition, as hypothesized for loggerheads, males on the periphery of mating groups could be more susceptible to predation (Heithaus et al. 2005). Yet, the lack of a sex effect for all injury types in the present study suggests that any behavioural variation between male and female leatherbacks may not increase the susceptibility of either group to threats that manifest in physical injuries.

Research on stranded loggerhead sea turtles (mostly juveniles) has found size effects, with individuals stranding due to anthropogenic causes being significantly larger than those stranding due to natural causes, perhaps due in part to fishing gear (i.e. hook) selectivity (Tomás et al. 2008, Bellido et al. 2010). Leatherbacks tend to be more vulnerable to entanglement in fishing gear, rather than directly ingesting baited hooks (Watson et al. 2005, Work \& Balazs 2010); therefore, they may be less likely to exhibit size differences in anthropogenic injury rates due to gear selectivity. While we tested for size effects in the present analysis, the lack of significance might reflect the narrow size range of the animals available for study, as only large subadult and mature animals utilize high-latitude foraging habitat in Canada (James et al. 2007), and only adult females are encountered on the nesting beach. Furthermore, if healing of many types of injuries in leatherbacks proceeds to the extent that they become imperceptible, this would surely confound investigation of size or age effects on prevalence of injuries.

As opportunistic sampling did not allow for repeated examinations of multiple individuals over time, how healing progresses, and the extent to which injuries of different types remain conspicuous and readily detected using our current examination protocols over the long term, is not understood. While observations of fresh (acute) injuries were relatively infrequent during random sampling of turtles at both field sites, future directed sampling of nesting turtles presenting with fresh injuries might allow for repeated examination of individuals between nesting events (within season), and between nesting seasons, facilitating study of the healing process in this species. Moreover, there is some indication that the incidence of fresh injuries may vary with nesting location. For example, Perrault et al. (2012) noted that up to $50 \%$ of Florida nesting leatherbacks had recent or healing injuries. Therefore, healing outcome studies might be most productively implemented at multiple nesting sites. Accounts from nesting beach monitoring programmes suggest that many wounds heal very quickly (i.e. even during the $\sim 10 \mathrm{~d}$ inter-nesting interval for some severe wounds), and may even completely disappear (Fretey 1993). Thus, many older, well-healed injuries likely went undetected during our injury assessments. 
In the present study, no difference was found in the proportion of all injuries located among all 4 flippers. However, the majority of injuries we observed were associated with the shoulder region, with significantly more associated with the left $(57.3 \%)$ versus the right $(42.7 \%)$ side. At a nesting beach in French Guiana in the 1980s, Fretey (1982) also found more injuries associated with the left side, but in that case it was the left flippers (both front and rear), and not the left shoulder region, that accounted for the majority of injuries $(75 \%)$. The present study's finding of more injuries in the left shoulder region is likely a product of hooking-related injury, as the majority of leatherbacks with injuries indicative of hooking had only 1 shoulder $(71.9 \%)$ affected, and for those turtles, the left shoulder was primarily implicated (75\%). The predominance of left versus right in shoulder injuries found here, and Fretey's (1982) finding of more left flipper damage, could be a function of lateralized behaviour. Nesting female leatherbacks have been shown to exhibit weak population-level preference for the right rear flipper to cover the egg chamber during ovipositioning (Sieg et al. 2010). Thus, if leatherbacks favour the right side in a variety of behaviours, they may favourably turn to the right when facing threats, exposing the left side of the body to injury.

A review of published data suggests that quantification of external injuries in leatherback sea turtles is not widely practiced (or at least published), and detailed injury assessments have not been conducted in temperate Northwest Atlantic foraging areas - where both sexes and subadults may be sampled - or on nesting beaches since the 1980s (Fretey 1982). Here, external injury assessments of leatherback sea turtles in a high-use temperate foraging region and at a Caribbean nesting beach were used to investigate the relative importance of direct anthropogenic and natural (predation) threats to the Northwest Atlantic population. Conclusions drawn from this work are limited to leatherbacks that survive injury-inflicting interactions, and inferences cannot be made about the relative contribution of different anthropogenic and natural hazards to mortality. However, our results suggest that large subadult and adult leatherbacks may face much higher levels of threat resulting in physical injuries from anthropogenic versus natural sources, and that these threats are not size or sex selective, and impact turtles in both sampling areas. A review of published literature suggests that injury assessments to clarify injury rates from suspected anthropogenic versus natural causes (i.e. predation) or to explore potential variation between groups (i.e. sex, or size or age), or geographic areas are rare. Research studies on small cetaceans have found similar results to the present study, with higher rates of injury attributed to fisheries interactions or vessel strikes than to predators (Luksenburg 2014), or with differences between species related to differential habitat use and corresponding variation in the magnitude of potential fisheries interactions (Kiszka et al. 2008). In another study, whale sharks were found to have similar predator-linked and vessel strike-linked injury rates, but with sample site differences (Speed et al. 2008).

Threat assessment research remains a priority for sea turtle conservation efforts (Hamann et al. 2010), but evaluation of the relative importance of direct threats to wildlife species that are long lived and rarely encountered can be difficult. While sampling only survivors and mainly attributing injuries to probable (versus confirmed) sources based on characteristic wounds and scarring patterns presents some limitations, detailed external injury assessments of individuals exist as a valuable tool for assessing the nature, severity, and prevalence of direct threats to local, and, in this case, broader populations of marine animals.

Acknowledgements. We gratefully acknowledge Fisheries and Oceans Canada, Fitzhenry Family Foundation, and the Horne Family Charitable Foundation for financial support of this research. We thank the Canadian Sea Turtle Network (Halifax, NS), J. Comeau, B. Fricker, K. Hamelin, B. Mitchell, and the Nature Seekers (Trinidad, WI) for assistance in the field. Thanks to S. Eckert and T. Wimmer for encouraging pursuit of this work. Fieldwork in Canada was conducted under Fisheries and Oceans Canada Scientific Licence \#332697 and \#323354. Fieldwork in Trinidad was conducted under Special Game License issued by the Ministry of the Environment and Water Resources, Wildlife section, Forestry Division.

\section{LITERATURE CITED}

Alfaro-Shigueto J, Mangel JC, Darquea J, Donoso M, Baquero A, Doherty PD, Godley BJ (2018) Untangling the impacts of nets in the southeastern Pacific: rapid assessment of marine turtle bycatch to set conservation priorities in small-scale fisheries. Fish Res 206:185-192

Álvarez de Quevedo IA, Félix MS, Cardona L (2013) Mortality rates in by-caught loggerhead turtle Caretta caretta in the Mediterranean Sea and implications for the Atlantic populations. Mar Ecol Prog Ser 489:225-234

*Bacon PR (1970) Studies on the leatherback turtle, Dermochelys coriacea (L.), in Trinidad, West Indies. Biol Conserv 2:213-217

Bellido JJ, Báez JC, Castillo JJ, Pinto F, Martín JJ, Mons JL, Real R (2010) Loggerhead strandings and captures along the southern Spanish coast: body size-based differences in natural versus anthropogenic injury. Chelonian Conserv Biol 9:276-282 
Bennett AM, Litzgus JD (2014) Injury rates of freshwater turtles on a recreational waterway in Ontario, Canada. J Herpetol 48:262-266

Bolten AB, Crowder LB, Dodd MG, MacPherson SL and others (2011) Quantifying multiple threats to endangered species: an example from loggerhead sea turtles. Front Ecol Environ 9:295-301

Bourgeois S, Gilot-Fromont E, Viallefont A, Boussamba F, Deem SL (2009) Influence of artificial lights, logs and erosion on leatherback sea turtle hatchling orientation at Pongara National Park, Gabon. Biol Conserv 142:85-93

Caldwell DK, Caldwell MC (1969) Addition of the leatherback sea turtle to the known prey of the killer whale, Orcinus orca. J Mammal 50:636

Camedda A, Marra S, Matiddi M, Massaro G and others (2014) Interaction between loggerhad sea turtles (Caretta caretta) and marine litter in Sardinia (Western Mediterranean Sea). Mar Environ Res 100:25-32

* Casale P (2011) Sea turtle by-catch in the Mediterranean. Fish Fish 12:299-316

Cecala KK, Gibbons JW, Dorcas ME (2009) Ecological effects of major injuries in diamondback terrapins: implications for conservation and management. Aquat Conserv 19:421-427

Chaloupka M, Work TM, Balazs GH, Murakawa SKK, Morris $\mathrm{R}$ (2008) Cause-specific temporal and spatial trends in green sea turtle strandings in the Hawaiian Archipelago (1982-2003). Mar Biol 154:887-898

*Donlan CJ, Wingfield DK, Crowder LB, Wilcox C (2010) Using expert opinion surveys to rank threats to endangered species: a case study with sea turtles. Conserv Biol 24:1586-1595

Duncan EM, Botterell ZLR, Broderick A, Galloway TS, Lindeque PK, Nuno A, Godley BJ (2017) A global review of marine turtle entanglement in anthropogenic debris: a baseline for further action. Endang Species Res 34: 431-448

Eckert SA (2006) High-use oceanic areas for Atlantic leatherback sea turtles (Dermochelys coriacea) as identified using satellite telemetered location and dive information. Mar Biol 149:1257-1267

Eckert KL, Wallace BP, Frazier JG, Eckert SA, Pritchard PCH (2012) Synopsis of the biological data on the leatherback sea turtle (Dermochelys coriacea). USFWS Biological Technical Publication. BTP-R4015-2012. http:// seaturtle.org/library/EckertKL_2012_USFWSTechReport .pdf

Fiedler FN, Sales G, Giffoni BB, Monteiro-Filho ELA, Secchi ER, Bugoni L (2012) Driftnet fishery threats sea turtles in the Atlantic Ocean. Biodivers Conserv 21:915-931

Fish MR, Côté IM, Gill JA, Jones AP, Renshoff S, Watkinson AR (2005) Predicting the impact of sea-level rise on Caribbean sea turtle nesting habitat. Conserv Biol 19:482-491

Fossette S, Kelle L, Girondot M, Goverse E and others (2008) The world's largest leatherback rookeries: a review of conservation-oriented research in French Guiana/Suriname and Gabon. J Exp Mar Biol Ecol 356:69-82

Fretey J (1982) Note sur les traumas observés chez des tortues luths adultes Dermochelys coriacea (Vandelli) (Testudines, Dermochelyidae). Rev Fr d'Aquariologie 8(4):119-128

Fretey J (1993) A technique for identifying adult female leatherback turtles by their injuries. In: Proceedings of the first international congress of Chelonian pathology 25-27, April 1992. Gonfaron, France, p 42-56
Guirlet E, Das K, Thomé JP, Girondot M (2010) Maternal transfer of chlorinated contaminants in the leatherback turtles, Dermochelys coriacea, nesting in French Guiana. Chemosphere 79:720-726

*Hamann M, Godfrey MH, Seminoff JA, Arthur K and others (2010) Global research priorities for sea turtles: informing management and conservation in the 21 st century. Endang Species Res 11:245-269

*Hamelin KM, James MC, Ledwell W, Huntington J, Martin K (2017) Incidental capture of leatherback sea turtles in fixed fishing gear off Atlantic Canada. Aquat Conserv 27:631-642

Harris HS, Benson SR, Gilardi KV, Poppenga RH, Work TM, Dutton PH, Mazet JA (2011) Comparative health assessment of western Pacific leatherback turtles (Dermochelys coriacea) foraging off the coast of California, 2005-2007. J Wildl Dis 47:321-337

*Heithaus R (2001) Shark attacks on bottlenose dolphins (Tursiops Aduncus) in Shark Bay, Western Australia: attack rate, bite scar frequencies, and attack seasonality. Mar Mamm Sci 17:526-539

* Heithaus M, Frid A, Dill L (2002) Shark-inflicted injury frequencies, escape ability, and habitat use of green and loggerhead turtles. Mar Biol 140:229-236

*Heithaus MR, Frid A, Wirsing AJ, Bejder L, Dill LM (2005) Biology of sea turtles under risk from tiger sharks at a foraging ground. Mar Ecol Prog Ser 288:285-294

*Heithaus MR, Wirsing AJ, Thomson JA, Burkholder DA (2008) A review of lethal and non-lethal effects of predators on adult marine turtles. J Exp Mar Biol Ecol 356: 43-51

* Hilterman ML, Goverse E (2007) Nesting and nest success of the leatherback turtle (Dermochelys coriacea) in Suriname, 1999-2005. Chelonian Conserv Biol 6:87-100

* Hirth HF, Kasu J, Mala T (1993) Observations on a leatherback turtle Dermochelys coriacea nesting population near Piguwa, Papua New Guinea. Biol Conserv 65:77-82

Horrocks J (1989) Leatherback injured off Barbados, West Indies. Mar Turtle Newsl 46:9-10

* Innis C, Merigo C, Dodge K, Tlusty M and others (2010) Health evaluation of leatherback turtles (Dermochelys coriacea) in the northwestern Atlantic during direct capture and fisheries gear disentanglement. Chelonian Conserv Biol 9:205-222

* James MC, Eckert SA, Myers RA (2005a) Migratory and reproductive movements of male leatherback turtles (Dermochelys coriacea). Mar Biol 147:845-853

James MC, Ottensmeyer CA, Myers RA (2005b) Identification of high-use habitat and threats to leatherback sea turtles in northern waters: new directions for conservation. Ecol Lett 8:195-201

James MC, Sherrill-Mix SA, Martin K, Myers RA (2006) Canadian waters provide critical foraging habitat for leatherback sea turtles. Biol Conserv 133:347-357

James M, Sherrill-Mix S, Myers R (2007) Population characteristics and seasonal migrations of leatherback sea turtles at high latitudes. Mar Ecol Prog Ser 337:245-254

Kappel CV (2005) Losing pieces of the puzzle: threats to marine, estuarine, and diadromous species. Front Ecol Environ 3:275-282

Kiszka J, Pelourdeau D, Ridoux V (2008) Body scars and dorsal fin disfigurements as indicators interaction between small cetaceans and fisheries around the Mozambique Channel island of Mayotte. West Indian Ocean J Mar Sci $7: 185-193$ 
Knowlton AR, Kraus SD (2001) Mortality and serious injury of northern right whales (Eubalaena glacialis) in the western North Atlantic Ocean. J Cetacean Res Manag 2:193-208

Knowlton AP, Hamilton PK, Marx MK, Pettis HM, Kraus SD (2012) Monitoring North Atlantic right whale Eubalaena glacialis entanglement rates: a $30 \mathrm{yr}$ retrospective. Mar Ecol Prog Ser 466:293-302

Komoroske LM, Lewison RL (2015) Addressing fisheries bycatch in a changing world. Front Mar Sci 2:83

Lawler JJ, Campbell SP, Guerry AD, Kolozsvary MB and others (2002) The scope and treatment of threats in endangered species recovery plans: an assessment of monitoring efforts in endangered species recovery plans. Ecol Appl 12:663-667

Leeney RH, Amies R, Broderick AC, Witt MJ, Loveridge J, Doyle J, Godley BJ (2008) Spatio-temporal analysis of cetacean strandings and bycatch in a UK fisheries hotspot. Biodivers Conserv 17:2323-2338

Lewison RL, Crowder LB (2007) Putting longline bycatch of sea turtles into perspective. Conserv Biol 21:79-86

Lewison RL, Freeman SA, Crowder LB (2004) Quantifying the effects of fisheries on threatened species: the impact of pelagic longlines on loggerhead and leatherback sea turtles. Ecol Lett 7:221-231

Lewison RL, Crowder LB, Wallace BP, Moore JE and others (2014) Global patterns of marine mammal, seabird, and sea turtle bycatch reveal taxa-specific and cumulative megafauna hotspots. Proc Natl Acad Sci USA 111: 5271-5276

Livingstone SR (2006) Sea turtle ecology and conservation on the north coast of Trinidad, West Indies. PhD thesis, University of Glasgow

Long DJ (1993) Records of white shark-bitten leatherback sea turtles along the Central California Coast. In: Ainley DG, Klimley AP (eds) Great white sharks: the biology of Carcharodon carcharias. Academic Press, San Diego, CA, p 317-319

Luksenburg JA (2014) Prevalence of external injuries in small cetaceans in Aruban waters, Southern Caribbean. PLOS ONE 9:e88988

Kum LL (2006) Assessment of incidental sea turtle catch in the artisanal gillnet fishery in Trinidad and Tobago, West Indies. Appl Herpetol 3:357-368

Mancini A, Koch V (2009) Sea turtle consumption and black market trade in Baja California Sur, Mexico. Endang Species Res 7:1-10

Marshall AD, Bennett MB (2010) The frequency and effect of shark-inflicted bite injuries to the reef manta ray Manta alfredi. Afr J Mar Sci 32:573-580

Martin K, James MC (2005a) Conserving sea turtles in Canada: successful community-based collaboration between fishers and scientists. Chelonian Conserv Biol 4:899-907

Martin K, James M (2005b) The need for altruism: engendering a stewardship ethic amongst fishers for the conservation of sea turtles in Canada. Marit Stud 3:105-118

* McCallum HI, Endean R, Cameron AM (1989) Sublethal damage to Acanthaster planci as an index of predation pressure. Mar Ecol Prog Ser 56:29-36

Moore MJ, van der Hoop JM (2012) The painful side of trap and fixed net fisheries: chronic entanglement of large whales. J Mar Biol 2012:230653

Moore JE, Cox TM, Lewison RL, Read AJ and others (2010) An interview-based approach to assess marine mammal and sea turtle captures in artisanal fisheries. Biol Conserv 143:795-805
Mrosovsky N, Ryan GD, James MC (2009) Leatherback turtles: the menace of plastic. Mar Pollut Bull 58:287-289

*Murray KT (2015) The importance of location and operational fishing factors in estimating and reducing loggerhead turtle (Caretta caretta) interactions in U.S. bottom trawl gear. Fish Res 172:440-451

*Murtaugh PA (1981) Inferring properties of mysid predation from injuries to Daphnia. Limnol Oceanogr 26:811-821

* Nemiroff L, Wimmer T, Daoust PY, McAlpine DF (2010) Cetacean strandings in the Canadian Maritime provinces, 1990-2008. Can Field Nat 124:32-44

Oviedo L, Esteves MA, Alfe E, Acevedo R, BolañosJiménez J (2009) Interaction between killer whales (Orcinus orca) and a leatherback turtle (Dermochelys coriacea) off northeastern coast Venezuela. Mar Biodivers Rec 2:e51

* Peckham SH, Maldonado Diaz D, Koch V, Mancini A, Gaos A, Tinker MT, Nichols WJ (2008) High mortality of loggerhead turtles due to bycatch, human consumption and strandings at Baja California Sur, Mexico, 2003 to 2007. Endang Species Res 5:171-183

* Perrault JR, Miller DL, Eads E, Johnson C, Merrill A, Thompson LJ, Wyneken J (2012) Maternal health status correlates with nest success of leatherback sea turtles (Dermochelys coriacea) from Florida. PLOS ONE 7: e31841

* Perrault JR, Miller DL, Garner J, Wyneken J (2013) Mercury and selenium concentrations in leatherback sea turtles (Dermochelys coriacea): population comparisons, implications for reproductive success, hazard quotients and directions for future research. Sci Total Environ 463-464: $61-71$

R Core Team (2016) R: a language and environment for statistical computing. R Foundation for Statistical Computing, Vienna. www.R-project.org

Reimchen TE (1988) Inefficient predators and prey injuries in a population of giant stickleback. Can J Zool 66: 2036-2044

* Reina RD, Abernathy KJ, Marshall GJ, Spotila JR (2005) Respiratory frequency, dive behaviour and social interactions of leatherback turtles, Dermochelys coriacea during the inter-nesting interval. J Exp Mar Biol Ecol 316: $1-16$

Revuelta O, León YM, Broderick AC, Feliz P and others (2015) Assessing the efficacy of direct conservation interventions: clutch protection of the leatherback marine turtle in the Dominican Republic. Oryx 49:677-686

* Richardson PB, Broderick AC, Coyne MS, Gore S (2013) Leatherback turtle conservation in the Caribbean UK overseas territories: Act local, think global? Mar Pol 38: 483-490

Robbins J, Mattila D (2004) Estimating humpback whale entanglement rates on the basis of scar evidence. Report to the Northeast Fisheries Science Center National Marine Fisheries Service, Woods Hole, MA

Roe JH, Clune PR, Paladino FV (2013) Characteristics of a leatherback nesting beach and implications for coastal development. Chelonian Conserv Biol 12:34-43

Saumure RA, Herman TB, Titman RD (2007) Effects of haying and agricultural practices on a declining species: the North American wood turtle, Glyptemys insculpta. Biol Conserv 135:565-575

Schuyler Q, Hardesty BD, Wilcox C, Townsend K (2014) Global analysis of anthropogebic debris ingestion by sea turtles. Conserv Biol 28:129-139 
Sieg AE, Zandonà E, Izzo VM, Paladino FV, Spotila JR (2010) Population level 'flipperedness' in the eastern Pacific leatherback turtle. Behav Brain Res 206:135-138

Speed CW, Meekan MG, Rowat D, Pierce SJ, Marshall AD, Bradshaw CJA (2008) Scarring patterns and relative mortality rates of Indian Ocean whale sharks. J Fish Biol 72:1488-1503

Stewart KR, Keller JM, Templeton R, Kucklick JR, Johnson C (2011) Monitoring persistent organic pollutants in leatherback turtles (Dermochelys coriacea) confirms maternal transfer. Mar Pollut Bull 62:1396-1409

Stewart KR, James MC, Roden S, Dutton PH (2013) Assignment tests, telemetry and tag-recapture data converge to identify natal origins of leatherback turtles foraging in Atlantic Canadian waters. J Anim Ecol 82:791-803

Tomás J, Gozalbes P, Raga JA, Godley BJ (2008) Bycatch of loggerhead sea turtles: insights from 14 years of stranding data. Endang Species Res 5:161-169

Tomillo PS, Saba VS, Piedra R, Paladino FV, Spotila JR (2008) Effects of illegal harvest of eggs on the population decline of leatherback turtles in Las Baulas Marine National Park, Costa Rica. Conserv Biol 22:1216-1224

Turtle Expert Working Group (2007) An assessment of the leatherback turtle population in the Atlantic Ocean. NOAA Tech Memo NMFS-SEFSC 555:116

Editorial responsibility: Jeffrey Seminoff,

La Jolla, California, USA
Venables WN, Ripley BD (2002) Modern applied statistics with S, 4th edn. Springer, New York, NY

*Wallace BP, Lewison RL, McDonald SL, McDonald RK and others (2010) Global patterns of marine turtle bycatch. Conserv Lett 3:131-142

Wallace BP, DiMatteo AD, Bolten AB, Chaloupka MY and others (2011) Global conservation priorities for marine turtles. PLOS ONE 6:e24510

*Wallace BP, Schumacher J, Seminoff JA, James MC (2014) Biological and environmental influences on the trophic ecology of leatherback turtles in the northwest Atlantic Ocean. Mar Biol 161:1711-1724

Wallace BP, Zolkewitz M, James MC (2015) Fine-scale foraging ecology of leatherback turtles. Front Ecol Evol 3: $1-15$

*Watson JW, Epperly SP, Shah AK, Foster DG (2005) Fishing methods to reduce sea turtle mortality associated with pelagic longlines. Can J Fish Aquat Sci 62:965-981

Work TM, Balazs GH (2010) Pathology and distribution of sea turtles landed as bycatch in the Hawaii-based North Pacific pelagic longline fishery. J Wildl Dis 46: 422-432

Work PA, Sapp AL, Scott DW, Dodd MG (2010) Influence of small vessel operation and propulsion system on loggerhead sea turtle injuries. J Exp Mar Biol Ecol 393:168-175

Submitted: January 2, 2018; Accepted: August 7, 2018

Proofs received from author(s): October 3, 2018 